\title{
Analysis of Financial and Non-Financial Performance of Marine Capture Fisheries Using Gillnet in Baai Island Port of Bengkulu Province
}

\author{
Yohana Tambunan, Ketut Sukiyono, and Mustopa Romdhon
}

Department of Agricultural Socio-Economic, Faculty of Agriculture, University of Bengkulu, Indonesia

\begin{abstract}
This study is aimed at analyzing the financial and non-financial performance of marine capture fisheries business in Baai Island Port. Stratified random sampling including 60 fishermen using gillnet fishing gear in Baai Island Port was used in this survey. The method used both financial performance including the analysis of income, B/C, Break Even Point (BEP), and non-financial performance including the analysis of the productivity of fishing gear, fishermen and fishing trip. The analysis showed that the income of fishermen in Baii Island was IDR $1,880,545$ per trip, the B/C was 0.25 , the BEP (unit) was $322 \mathrm{~kg}$, and the productivity of fishing gear was $8 \mathrm{~kg}$ per unit, the fishermen productivity was $72 \mathrm{~kg}$ per person and the catching productivity was $30 \mathrm{~kg}$ per trip.
\end{abstract}

Keywords: B/C, financial performance, fishing, income, non-financial performance, productivity

Received 24 February 2018 | Revised 12 Maret 2018 | Accepted 18 Maret 2018

\section{Introduction}

As a country with a large water area, Indonesia's marine and fishery resources have tremendous potential to become the foundation of natural resource-based economic development. According to Hermawan [1], only $15 \%$ of fishery business in Indonesia is categorized as a large scale fishery business, while the rest $(85 \%)$ is a small scale fishery business. The similar situation is also found in Bengkulu, especially the one experienced by fishing vessels that docked or anchored at the Fish Landing Base (PPI) of Baai Island. Baai Island Port is one of the main fishing ports in Bengkulu Province serving as the central stop of ships as well as the fishing center in Bengkulu City. Baai Island Port is located in Bengkulu Province, approximately $25 \mathrm{~km}$ to the south of Bengkulu City. One of the fishing gear types widely used by fishermen community in Baai Island fishing port is gillnet due to its relatively low price enabling fishermen to afford to purchase it. In relation to the common use of gillnet as the fishing gear, the author has not found any study measuring the performance of fisheries business based on the fishing gear used in this area.

*Corresponding author at: Department of Agricultural Socio-Economic, Faculty of Agriculture, University of Bengkulu, Jl. WR. Supratman Kandang Limun, Bengkulu, Indonesia

E-mail address: ksukiyono@unib.ac.id 
Performance measurement is both financial and non-financial performance measurements [2]. Van Gijsel [3] states that financial performance measurement is only oriented to the financial sector, while non-financial performance measurement measures the efficiency of the input use. Performance measurement generally focuses more on the use of financial performance indicators as the key indicator of performance measurement and evaluation. Besides, it is also used in the analysis of the fishermen performance [4]. Nevertheless the use of such indicator was criticized, among others, by Norreklit [5].

According to Kaplan and Norton [6], the performance measurement that only focuses on the financial sector has less ability to talk a lot about the past business entity. Furthermore, Neely (1999) says that in today's business environment, where companies compete based on nonfinancial indicators, they need information about their performance across a broader spectrum of dimensions, not only about their financial performance but also about such other factors as customers, employees, suppliers and society. The combination of financial and non-financial indicators can produce balanced performance measurements in a business environment [6]. Therefore, Speckbacher et al. [7] strongly recommend to involve non-financial performance measurement so that managers are well informed about their business. A number of management literatures have tried to link financial with non-financial performance measures. In general, it can be concluded that non-financial performance measures can be indicators of current or future performance [8][9]). However, more research is needed to examine how nonfinancial performance measures are related to achieving the increased profit and organizational outcomes. For these reasons, this research is conducted to measure financial and non-financial performance of marine capture fisheries businesses in Baai Island Port, especially those using gillnet fishing gear.

\section{Method}

This research was conducted at the Fish Landing Base of Baai Island, Kampung Melayu Subdistrict, Bengkulu City. The surveys were conducted in May 2015 during the West Wind season which was usually characterized by high winds and relatively high waves. In such conditions, the level of productivity or fishermen's catches encountered obstacles possibly leading to financial performance effects. Thus it is more likely to do an analysis on the risk of failure of the marine capture fisheries business due to the storms and the like.

This research used a quantitative descriptive research method to describe the circumstances, objects or real events at the time of the study. The population in this study was the fishermen running a business on marine capture fisheries using gillnet fishing gear in Baai Island. With the ship ranging in size used by the fishermen, the sample was taken using a Stratified Random Sampling method developed by Roscoe (1975 in Sukiyono [10]). The strata used in this study were the small vessels with the capacity of $4-9$ GT and the medium vessels with the capacity 
of more than $9 \mathrm{GT}$, from each of which 30 samples were taken. The respondents in the study were the ship owners and/or the shipmasters. The data collected from the respondents through a structured interview include production, fishing trip costs, fish price, profit, income and fishing area.

The assessments on the business performance of PPI of Baai Island were conducted through financial and non-financial analysis. The financial analysis of marine capture fisheries business includes profit, B/C Ratio and Break Event Point (BEP) analysis to find out the extent of the success that has been achieved by the marine capture fisheries business using gillnet. Details of the financial performance assessment are as follows.

\subsection{Profit $(\pi)$}

Profit is the nominal amount obtained from the difference between income and expense. This analysis aims at measuring whether the current business activity is successful or not. This analysis can be used to determine the amount of profit obtained from the business activity being carried out (Umar, 2003 in Rahmi et al. [11]). The profit calculation was done by the formula:

$$
\pi=\mathrm{TR}-\mathrm{TC}
$$

where $\pi=$ Profit, $\mathrm{TR}=$ Total Revenue, and $\mathrm{TC}=$ Total Cost

\subsection{Benefit Cost Ratio (B/C)}

The benefit-cost ratio can also be calculated by comparing the profit or the net income of the business with the total cost of the business production. The statement can be written with the following formula [12]:

$$
B / C=\frac{\pi}{T C}
$$

a. If $\mathrm{B} / \mathrm{C}>0$, then a farm business is said to provide benefits for business actors or it is a feasible business.

b. If $\mathrm{B} / \mathrm{C}=0$, then a farm business is said to break even or it gives neither a profit nor a loss.

c. If $\mathrm{B} / \mathrm{C}<0$, then a farm business is said to provide no benefits for business actors or it is not a feasible business.

\subsection{Break Even Point (BEP)}

Break even point is a situation where a company operation does not get a profit or loss (income $=$ total cost). In this analysis, the types and the price of fish were ignored because of a large variety of the fish caught. The calculation was based only on the total production and the average price of the fish without considering the types of the fish. 
The formula used for Break Even Point [13] was:

i. On the basis of value $\quad B E P=\frac{F C}{1-\frac{V C}{S}}($ IDR)

ii. On the basis of quantity $B E P=\frac{F C}{P-V C}$ (unit)

where $\mathrm{FC}=$ Fixed Cost, $\mathrm{VC}=$ Variable Cost per Unit, $\mathrm{P}=$ Price per Unit, $\mathrm{S}=$ Sale

The assessment on non-financial performance in this research was done by analyzing the productivity. The productivity measurements of fishing gear included the productivity per unit of fishing gear, per person and per fishing trip. Such productivity measurements had also been done by Wahyuningrum et al. [14]. In this study, the productivity measurements were analyzed using the development and modification of the formula proposed by Gaspersz [15] by ignoring the types of fish:

$$
\begin{aligned}
& \text { Productivity of the fishisng gear }=\frac{\text { Total output }}{\text { The number of fis } \text { geras }}(\mathrm{kg} / \mathrm{unit}) \\
& \text { Productivity of the crew }=\frac{\text { Total Output }}{\text { The number of Crew }}(\mathrm{kg} / \mathrm{person}) \\
& \text { Producitivity of fishing trip }=\frac{\text { Total output }}{\text { The number of days of fishing trip }}(\mathrm{kg} / \mathrm{day})
\end{aligned}
$$

\section{Results and Discussion}

\subsection{Characteristics of Fishing Vessels with Gillnet Fishing Gear}

Most of fishing vessels at the Baai Island Port are 4 - 6 GT (Gross Tone). Gross tone is a measure that indicates the capacity or volume of a ship's enclosed spaces and is considered watertight inside the ship [16]. Normally, ship owners buy a new ship in the lightweight of 6 GT that costs IDR 127,200,000. The ship in lightweight means the ship without additional machines. The price of the ship will change depending on the condition of the ship itself. The economic value of the ship may increase if it is sold in a good condition and will decrease dramatically if it is not in good condition or in a damaged condition. A ship is also equipped with communication tools such as radios and such other supporting tools as a compass and a Global Position System (GPS) used for navigating.

According to the data from the Municipal Office of Maritime Affairs and Fisheries of Bengkulu [17], a total of 140 fishermen in Baai Island Port used gillnet fishing gear; however, in this research, the researcher only took 60 fishermen who used gillnet fishing gear as the research object. The fishermen claimed that they used gillnet fishing gear because it was relatively cheap and was easy to locate; in addition, they were also more skilled in using this fishing gear than using other fishing gears. In one fishing trip, they would carry an average of 47 pieces of net. 
The commonly used engine types were Hyundai, Yandong, Mitsubishi and Yanmar with various PK (paardekracht or horse power). Generally the fishermen could only afford to buy used or second hand machines with an average price of IDR 22,946,667, with an average engine power of $32 \mathrm{PK}$. A total of $46.6 \%$ of fishermen used such engine power. They said that they could not afford to buy a new machine because its price was too expensive, more than IDR $50,000,000$. This ship's machine economical lifespan would last for 20 years depending on the maintenance by the ship owner.

The crew is the ship's crew other than the captain or the ship leader who has different duties and responsibilities. The crew's skills in catching fish affects the number of catches because the process of pulling down and drawing the fishing gear requires the level of agility to successfully catch the fish. The fishing vessels using gillnet fishing gear in the Baai Island Port of Bengkulu City had an average number of 5 crew per ship including the captain of the ship. Each of the crew operated a fishing gear and a person serving as the captain was in charge of providing direction and orders to the crew. Each of the crew members had different assignments. One of them was assigned as the helmsman responsible to navigate the ship to the fishing area and the other three crew members were assigned to help pull out the fish. Usually the crew members were their family members and neighbors who wanted to join a fishing trip. The number of crew members was also influenced by the size of the ship, if the ship were above 6 GT, it would require larger number of crew.

\subsection{The Cost of Marine Capture Fisheries Business}

The costs are classified into variable costs and fixed costs. The variable cost is the operational cost incurred by the fisherman per trip. The total production cost incurred by the fishery business owner can be seen in Table 1 .

Table 1. The Total Cost Incurred by the Fishery Business Owner in Baai Island

\begin{tabular}{clrcc}
\hline \multirow{2}{*}{ No } & \multicolumn{1}{c}{ Production Costs } & \multicolumn{3}{c}{ Costs (IDR) } \\
\cline { 3 - 5 } & & Trip & Year & $\begin{array}{c}\text { Percentage } \\
(\%)\end{array}$ \\
\hline \multirow{2}{*}{1} & $\begin{array}{l}\text { Variable Cost } \\
\bullet \quad \text { Operational cost }\end{array}$ & $5,896,667$ & $141,520,008$ & 79.76 \\
\hline \multirow{2}{*}{2} & Fixed Cost & & & \\
& $\bullet \quad$ Maintenance cost & 652,132 & $15,651,168$ & 8.82 \\
& $\bullet \quad$ Depreciation cost & 844,556 & $20,269,344$ & 11.42 \\
\hline & Total & $7,393,355$ & $177,440,520$ & 100.00 \\
\hline
\end{tabular}

Source: primary data (processed), 2015

The variable cost was the highest cost incurred by the fishermen in one year $(79.76 \%)$ followed by the costs of maintenance and depreciation. Higher variable costs were due to the length of time spent for the fishing trip which was directly proportional to the costs incurred by the fishermen. The longer time the fishermen spent for the fishing trip the higher operational costs would be incurred. The variable cost components affecting the fishing trip were Diesel Fuel, 
Consumption, Cigarettes, and Ice. Meanwhile, for the maintenance cost, the cost depended on how damaged the fisherman's investment goods were. The more often the treatment was required the higher the maintenance cost would be. The depreciation cost incurred by the fishermen depended on the economic life of the investment goods. The more often the investment goods were treated and the better condition they were the longer the economic life of the use of investment goods and the less cost incurred by the fishermen.

In one fishing trip, the fisherman spent an average of 12 days in the sea so that there were 2 fishing trips in a month and 24 trips in a year. The number of these fishing trips was assumed to be the minimum number of fishing trips carried out by the fishermen. The calculated cost was the operational cost. The type and the average variable cost of the marine capture fisheries business can be seen in Table 2.

Table 2. The Average Variable Cost of the Marine Capture Fisheries Business Using Gillnet Fishing Gear

\begin{tabular}{|c|c|c|c|c|c|}
\hline \multirow{2}{*}{ No } & \multirow{2}{*}{ Type } & \multirow{2}{*}{$\begin{array}{c}\text { The Number } \\
\text { of Fishing } \\
\text { Trips }\end{array}$} & \multicolumn{2}{|c|}{ Costs (IDR) } & \multirow{2}{*}{$\begin{array}{c}\text { Percentage } \\
(\%)\end{array}$} \\
\hline & & & Trip & Year & \\
\hline 1 & Diesel Fuel (liter) & 382 & $2,633,500$ & $63,204,000$ & 44.66 \\
\hline 2 & Consumption & $2,241,667$ & $2,241,667$ & $53,800,000$ & 38.01 \\
\hline 3 & (IDR) & 31 & 581,083 & $13,946,000$ & 9.85 \\
\hline \multirow[t]{2}{*}{4} & $\begin{array}{l}\text { Ice (Block) } \\
\text { Cigarette (Pack) }\end{array}$ & 29 & 440,417 & $10,570,000$ & 7.47 \\
\hline & Total & & $5,896,667$ & $141,520,000$ & 100.00 \\
\hline
\end{tabular}

Source: primary data (processed), 2015

The cost of diesel fuel incurred by the fishermen in the Baai Island Port varied depending on the distance of the fishing trip. For every trip, the fishermen spent on average of 382 liters where a liter of diesel fuel cost IDR 6,900; consequently, as the fishermen did 24 fishing trips in a year, the cost of the diesel fuel incurred by the fishermen was IDR 63,204,000 per year.

Food is an absolute necessity brought by the fishermen during the fishing trip, and the food (consumption) cost depended on the length of the fishing trip and the number of crew in the trip. The average cost of consumption spent by the fishermen for every 10 to 12 day fishing trip was IDR 2,241,667. The cost covered the consumption of all the crew during the fishing trip. In their research, Sukiyono and Romdhon [18] found that the average of 5.16 people brought in every fishing trip is the inefficient number of crew for marine capture fisheries business using gillnet fishing gear in Bengkulu City. The consumption cost incurred by the fisheries business owners included the wages of the fishermen. In addition to food, cigarettes have become a basic necessity for the fishermen. This was presumably due to the cold weather in the sea that made the fishermen smoke to create a sense of warmth. The other reason for the fishermen's smoking habit was their effort to get rid of boredom when there was no fishing activity. 
Ice block was needed by every fisherman to maintain the quality of the fish caught, thus none of them did not use ice blocks. Fishermen carry an average of 21 blocks of ice depending on the capacity of the ice box or fiber used. The price of ice used to be IDR 17,000 per block but in the recent weeks it was IDR 21,000 per block. As a result, most of small fishermen were unable to meet the need of fishing trip.

The fixed costs in this marine capture fisheries business included the maintenance cost and depreciation cost of the boats/ships, nets, and machinery requiring routine maintenance to keep its condition feasible and safe to be used for long periods of time. The portion of the acceptance used for equipment maintenance was in line with the depreciation expense. Table 3 shows the average maintenance cost incurred by the fishermen in their fisheries business.

Table 3. The Average Maintenance Costs in the Marine Capture Fisheries Business

\begin{tabular}{lcccc}
\hline \multirow{2}{*}{$\begin{array}{c}\text { Maintenance } \\
\text { Costs }\end{array}$} & $\begin{array}{c}\text { Frequency } \\
\text { (per year) }\end{array}$ & \multicolumn{2}{c}{ Costs (IDR) } & Percentage \\
\cline { 3 - 5 } & 3 & Trip & Year & (\%) \\
\hline Putty and paint & 13 & 240,799 & $5,779,167$ & 36.92 \\
Machinery & 18 & 193,778 & $4,650,672$ & 29.71 \\
Net & & 217,556 & $5,221,344$ & 33.37 \\
\hline Total & 652,132 & $15,651,167$ & 100.00
\end{tabular}

Source: primary data (processed), 2015

The details of the total depreciation cost are presented in Table 4 The average depreciation cost was IDR 855,773 in which the highest average value was the cost of ship depreciation (36.99 $\%$ ) followed by the cost for fishing gear, ice box or fiber, machinery, GPS and compass, respectively. The amount of depreciation cost depends on the economic life of each of the items in addition to their price.

Table 4. The Average Depreciation Cost of Fishing Using Gillnet Fishing Gear

\begin{tabular}{|c|c|c|c|c|}
\hline \multirow{2}{*}{ No } & \multirow{2}{*}{ Fixed Costs } & \multicolumn{2}{|c|}{ Costs (IDR) } & \multirow{2}{*}{$\frac{\text { Percentage }}{(\%)}$} \\
\hline & & Trip & Year & \\
\hline 1. & Ship & 316,621 & $7,598,904$ & 36.99 \\
\hline 2. & Fishing Gear & 310,489 & $7,451,736$ & 36.29 \\
\hline 3. & Ice Box & 133,676 & $3,208,234$ & 15.62 \\
\hline 4. & Machinery & 56,712 & $1,361,088$ & 6.62 \\
\hline 5. & Compass & 30,592 & 734,208 & 3.59 \\
\hline 6. & GPS & 7,682 & 184,368 & 0.89 \\
\hline & Total & 855,773 & $20,538,553$ & 100.00 \\
\hline
\end{tabular}

Source: primary data (processed), 2015

\subsection{Revenue}

The revenue of the marine capture fisheries business using gillnet was obtained from the multiplication of the catch per fishing trip with the selling price. The number of fish obtained by the fishermen every time they went to fishing trip could not be ascertained. The amount of the 
fishermen's revenue was determined by the number of catches obtained by the fishermen in every fishing trip. The following is the average number of the fishermen's catches in every fishing trip.

Table 5. The Average Number of the Catches per Ship in every Fishing Trip

\begin{tabular}{llccrrrr}
\hline No & $\begin{array}{c}\text { Type of } \\
\text { Fish }\end{array}$ & $\begin{array}{c}\text { Amount } \\
(\mathbf{k g} / \text { trip) }\end{array}$ & $\begin{array}{c}\text { Percentage } \\
(\mathbf{\%})\end{array}$ & Price & \multicolumn{1}{c}{ Revenue (IDR) } & Percentage \\
\hline 1 & Kerong & 127 & 21.72 & 8,000 & $1,016,400$ & \multicolumn{1}{c}{ Year } & \multicolumn{1}{c}{$(\mathbf{\%})$} \\
\hline 2 & $\begin{array}{l}\text { Kape- } \\
\text { kape }\end{array}$ & 87 & 13.79 & 32,000 & $2,794,667$ & $67,072,000$ & 10.95 \\
3 & Tenggiri & 38 & 8.34 & 40,000 & $1,506,667$ & $36,160,000$ & 16.26 \\
4 & Beledang & 31 & 11.20 & 15,000 & 470,500 & $11,292,000$ & 5.07 \\
5 & Gebur & 31 & 7.66 & 30,000 & $1,076,250$ & $25,830,000$ & 11.60 \\
6 & Kakap & 25 & 6.69 & 45,000 & $1,143,750$ & $27,450,000$ & 12.33 \\
7 & Bawal & 12 & 4.37 & 80,000 & 990,667 & $23,776,000$ & 10.68 \\
8 & Terusan & 7 & 9.84 & 30,000 & 215,000 & $5,160,000$ & 2.33 \\
9 & Talang & 4 & 16.39 & 15,000 & 60,000 & $1,440,000$ & 0.64 \\
\hline & Total & 362 & 100.00 & & $9,273,900$ & $222,573,600$ & 100.00 \\
\hline
\end{tabular}

Source: primary data (processed), 2015

Table 5 shows that the total catch of the fishermen in Baai Island was on average of $362 \mathrm{~kg}$ per 12 day fishing trip. The type of fish that was most frequently caught was kerong (127 kg/trip) and the least frequently caught fish was talang ( $4 \mathrm{~kg} /$ trip). Kerong was not the target of their fishing trip; however, it was accidentally the dominant type of fish they obtained during their last fishing trip in May 2015. The dominant catch of kerong did not put aside such other types of fish as tenggiri (mackerel), kakap (snapper) and bawal (pomfret).

\subsection{Financial Performance Analysis}

The financial analysis in this study was related to the results of the capital invested in the marine capture fisheries business, i.e. the income received by the fishermen. The measures in this study were divided into three, calculating (i) the income, (ii) B/C ratio, and (iii) break even point. The more details of the financial performance analysis can be seen in Table 6 .

Table 6. Financial Performance Analysis

\begin{tabular}{lrr}
\hline \multirow{2}{*}{ Description } & \multicolumn{2}{c}{ Average } \\
\cline { 2 - 3 } & Per trip & Per year \\
\hline Income (IDR) & $1,880,545$ & $45,133,080$ \\
B/C & 0.25 & 0.25 \\
BEP (Unit/kg) & 322 & 7,728 \\
BEP (Rupiah) & $8,236,863$ & $197,684,712$ \\
BEP of fishing trip (times) & - & 21 \\
\hline
\end{tabular}

Source: primary data (processed), 2015 


\subsection{Income}

The average income of the fishermen was IDR $1,880,545$ which would be classified as a small income because it was in the famine season. The famine season occured in February to May when the Southeast wind blew causing high wind waves and difficulty to get fish. According to some fishermen, this financial condition was extremely different from their income a year before.

The high cost of production also affected the fishermen's income. The increase in the input prices made the fishermen uninspired to do a fishing trip. However, in the absence of other alternatives, they still had to do such fisheries business. Besides, the fish prices at the fishermen's level were also still low, thus affecting the fishermen's income.

\section{6. $\mathrm{B} / \mathrm{C}$}

The finding shows that the value of $\mathrm{B} / \mathrm{C}$ Ratio was 0.25 , meaning that every 1 (one) rupiah spent will give a profit of 0.25 rupiah. This result means that the marine capture fisheries business using gillnet fishing gear in Baai Island is still feasible although the resulting profit is relatively small compared to, for example, Hendrik's [19] findings. In his research, Hendrik found that the value of B/C Ratio on the marine capture fisheries business using Gillnet in North Sumatra was 1.48. However, it needs to be noted that the marine capture fisheries business studied by Hendrik had ships with larger capacities, i.e. 24 GT. In addition, the seasonal or weather differences also affected the catch.

\subsection{Break Even Point (BEP)}

The results show that the break even point for each time of production was $322 \mathrm{~kg}$ (ignoring the type of fish) with a value of IDR $8,236,863$ per trip. This means that the fishermen had to be able to sell their catch more than $322 \mathrm{~kg}$ of fish or to get more than IDR 8,236,863 in order to avoid losses and to meet the production costs. Based on the number of fish caught per fishing trip (362 kg per trip), the fishermen in Baai Island have already surpassed the break even point, meaning that they got profit from their fishing trip. If the fishermen generally go for fishing trip as much as 24 trips a year with an average production of $362 \mathrm{~kg}$ per trip, then, with the minimum catch amount of $322 \mathrm{~kg}$ the fisherman must make a fishing trip at least 21 times in order not to lose. It should be noted that this unit of catch does not distinguish the type of fish. Further research should be more detailed considering the type of catch which is very important to get a more detailed picture of fishing trip.

\subsection{Non-Financial Performance Analysis}

In addition to financial factors, the performance of the fishermen can also be seen from nonfinancial factors, one of which is through the level of the fishermen's work productivity. The fishermen's productivity can be measured by calculating the level of fishing gear productivity, fisherman/crew productivity and per fishing trip productivity. 
Table 7. The Level of the Fishermen's Productivity in Baai Island

\begin{tabular}{clccc}
\hline No & \multicolumn{1}{c}{ Productivity } & Volume(kg) & Unit & Value (kg/unit) \\
\hline 1 & Fishing Gear (unit) & 362 & 47 & 8 \\
2 & Crew (person) & 362 & 5 & 72 \\
3 & Fishing Trip (day) & 362 & 12 & 30 \\
\hline
\end{tabular}

Source: primary data (processed), 2015

Table 7 shows that the productivity level of fishing gear was $8 \mathrm{~kg}$ per unit meaning that every single fishing gear was able to catch $8 \mathrm{~kg}$ of fish where the fishermen used an average of 47 units of fishing gear. Based on the processed data in 2015, 47 units of fishing gear were not the largest number of fishing gears used by the fishermen. Some fishermen used more fishing gears to get more fish that would in turn increase their income. Each of fishing gear units was different one another, and different types of fishing gear required different nets. So the more fishing gears were used the more fishermen would be needed to operate them. Nevertheless, the more number of fishermen did not necessarily increase the productivity of the fishermen because the catch was not influenced by the number of crew. However, the number of crew was influenced by the ship size because the larger the size of the ship required a larger number of crew. The results of productivity calculation showed that the fishermen productivity level was $72 \mathrm{~kg}$ per person, meaning that each fisherman could catch $72 \mathrm{~kg}$ of fish. Meanwhile, the fishing trip productivity was $30 \mathrm{~kg}$ per day. The longer the fishing trip was the more fishermen would have the opportunity to get more catches. If the fishermen took a relatively long fishing trip, they could roam up to various fishing areas that were still within the boundaries of the fishing grounds.

\section{Conclusion and Recommendation}

\subsection{Conclusion}

The performance of marine capture fisheries business with gillnet fishing gear was financially indicated by the amount of income value, B/C and Break Even Point. In terms of income, the marine capture fisheries business with gillnet fishing gear earned IDR $1,880,545$ per trip or IDR 45,133,080 per year within 24 fishing trips. The level of business efficiency as reflected by the $\mathrm{B} / \mathrm{C}$ ratio showed that this marine capture fisheries business had a $\mathrm{B} / \mathrm{C}$ ratio of 0.25 . In order not to get loss, the BEP value obtained for the break even point was $322 \mathrm{~kg}$ per unit of production with a value of IDR $8,236,863$. Meanwhile, the fishermen's non-financial performance was measured from the level of fishing gear productivity, fisherman productivity and fishing trip productivity. It was found that the fishing gear productivity was $8 \mathrm{~kg} /$ piece, the fishermen productivity was $72 \mathrm{~kg} /$ person and the fishing trip productivity was $30 \mathrm{~kg} /$ day. 


\subsection{Recommendation}

Based on the study conducted on the analysis of financial and non-financial performance of marine capture fisheries business with gillnet fishing gear in Baai Island Port, several recommendations are addressed. In order to develop and improve the marine capture fisheries business with gillnet fishing gear, the government should be more assertive to the use of trawling fishing gear. There should be an increase in the selling value of the fishermen's catch through marketing system improvement. Sorting the catch by the type and size of fish is expected to increase the sale value of the catch. In addition, it is necessary to optimally utilize the information from the Meteorology Climatology and Geophysics Council (BMKG) concerning the weather and the use of modern technology so as to improve the catch as well as to reduce the operational costs.

The main limitation of this study is that it does not distinguish the type of the fish caught, whereas the type of fish is very influential on the revenue which in turn will affect the performance of marine capture fisheries business. Therefore, research considering the variation of types of fish caught needs to be done in order to describe the performance of marine capture fisheries business in a more detailed circumstance.

\section{Notes}

This article is a part of the thesis entitled "Analysis of Financial and Non-financial Performance of Fisheries Business in Baai Island Port of Bengkulu Province" by Yohana Tambunan.

\section{REFERENCES}

[1] M. Hermawan, "Keberlanjutan perikanan tangkap skala kecil," Doctoral Thesis, Sekolah Pascasarjana IPB, Bogor, 2005.

[2] A. Neely, "The performance measurement revolution: why now and what next," International Journal of Operations \& Production Management, vol. 19, no. 2, pp. 205228, 1999.

[3] P. Van Gijsel, "The importance of non-financial performance measures during the economic crisis," Master Thesis, School of Economics and Management of Tilburg University, Tillburg, 2012.

[4] A. Kohar, A. Suherman, and M. A. Wijayanto, "Analisis Program dan Kinerja Pelabuhan Perikanan Nusantara (PPN) Pekalongan," J Saintek Perikanan, vol. 7, no. 1, pp. 32-38, 2010.

[5] H. Norreklit, "The balance on the balanced scorecard-a critical analysis of some of its assumptions," Management Accounting Research, vol. 1, no. 1, pp. 65-88, 2000.

[6] R.S. Kaplan and D. P. Norton, Balanced scorecard menerapkan strategi aksi. Jakarta: Erlangga, 2000.

[7] G. Speckbacher, J. Bischof, and T. Pfeiffer, "A descriptive analysis on the implementation of balanced scorecards in German-speaking Countries," Management Accounting Research, vol. 14, no. 4, pp. 361-387, 2003. 
[8] C. Ittner and D. Larcker. "Innovations in performance measurement: trends and research implications," Journal of Management Accounting Research, vol. 10, pp. 205-238, 1998.

[9] K. Hughes, "The Value relevance of non-financial measures of air pollution in the electric utility industry," The Accounting Review, vol. 75, no. 2, pp. 209-228, 2000.

[10] K. Sukiyono, Penelitian Survey dan Teknik Sampling. Bengkulu: Lab Sosial Ekonomi Pertanian UNIB, 2012.

[11] T. A. Rahmi, P. I. Wahyuningrum, and T. W. Nurani, "Usaha perikanan tangkap skala kecil di Sadeng Kabupaten Gunung Kidul Daerah Istimewa Yogyakarta," Jurnal Anasal, vol. 2, pp. 40-45, 2013.

[12] B. Cahyono, Wortel, Teknik Budi Daya dan Analisis Usaha Tani. Jakarta: Kanisius, 2002.

[13] B. Riyanto, Dasar-Dasar Pembelanjaan Perusahaan, 4th Edition. Yogyakarta: UGM Press, 1995.

[14] P. I. Wahyuningrum, T. W. Nurani, and T. A. Rahmi, "Usaha perikanan tangkap multi purposes di Sadeng, Kabupaten Gunung Kidul, Daerah Istimewa Yogyakarta," Maspari Journal, vol. 04, pp. 10-22, 2012.

[15] V. Gaspersz, Analisis Sistem Terapan Berdasarkan Pendekatan Teknik Industri. Bandung: Tarsito, 1992.

[16] Wikipedia, "Gross tonnage," Nov. 24, 2018, [Online]. Available: https://en.wikipedia.org/wiki/Gross_tonnage.

[17] Municipal Office of Maritime Affairs and Fisheries of Bengkulu, Data Pemilik Kapal dan Alat yang Digunakan Nelayan di Provinsi Bengkulu Pada Tahun 2012 - 2013, 2014.

[18] K. Sukiyono and M. M. Romdhon, "Efisiensi alokatif faktor produksi pada usaha perikanan tangkap di Kota Bengkulu: kasus pada alat tangkap gillnet," Jurnal Saintek Perikanan, vol. 11, no. 2, pp. 99-104, 2016.

[19] Hendrik, "Analisis usaha alat tangkap gillnet di Pandan Kabupaten Tapanuli Tengah Sumatera Utara," Jurnal Perikanan dan Kelautan, vol. 17, no. 2, pp. 28-35, 2012. 